\title{
JUKMAS
}

Jurnal Untuk Masyarakat Sehat (JUKMAS)

e-ISSN : 2715-7687

Vol. 4, No. 2 Oktober 2020

P-ISSN : 2715-8748

\section{Analisis Penggunaan Alat Kontrasepsi Sebelum Dan Saat Pandemi Covid-19}

\author{
Yuna Trisuci Aprillia ${ }^{1,3}$, Asyifa Robatul Adawiyah ${ }^{2}$, Santi Agustina ${ }^{1}$ \\ ${ }^{1}$ Prodi Kebidanan Sarjana Terapan Fakultas Ilmu Kesehatan URINDO \\ ${ }^{2}$ Prodi Kesehatan Masyarakat Fakultas IImu Kesehatan URINDO \\ ${ }^{3}$ Centre for Family and Ageing Studies (CeFAS) URINDO \\ yuna@urindo.ac.id
}

\begin{abstract}
Abstrak
WHO menyatakan penyakit virus korona (COVID-19) sebagai darurat kesehatan global. Pemerintah Indonesia telah menetapkan bencana non alam penyebaran COVID-19 sebagai Bencana Nasional. Dalam menghadapi wabah bencana non alam COVID-19 ini dilakukan kebijakan Pembatasan Sosial Berskala Besar (PSBB) untuk pencegahan penularan COVID-19. Kondisi ini menyebabkan dampak terhadap kelangsungan pelayanan kesehatan masyarakat, termasuk pelayanan KB dan kesehatan reproduksi. Penelitian ini menggunakan teknik kuantitatif dengan menggunakan survei cepat pada bulan Juni-Agustus 2020 menggunakan analisis Uji-T dependen. Sampel pada penelitian ini sebanyak 290 responden. Pada hasil analisis bivariat didapatkan bahwa tidak terdapat perbedaan antara penggunaan alat/obat/cara kontrasepsi sebelum dan saat pandemi, hal ini disebabkan bahwa jika kita lihat persentase tertinggi pada alat/obat/cara kontrasepsi yang digunakan adalah AKDR/IUD, sebagaimana yang diketahui bahwa AKDR/IUD merupakan Metode Kontrasepsi Jangka Panjang (MJKP). IUD merupakan salah satu alat kontrasepsi yang disarankan oleh ahli, memastikan penggunaan kontrasepsi yang tepat pada saat COVID-19 sangat penting. Kita mendorong perempuan, tenaga kesehatan (bidan, perawat dan dokter), pembuat kebijakan, dan masyarakat untuk mempertimbangkan layanan seksual dan kesehatan reproduksi sebagai prioritas.
\end{abstract}

Kata kunci: Alat Kontrasepsi, IUD, PUS, Pandemi, COVID-19, KB

\section{Abstract}

WHO declared the coronavirus disease (COVID-19) a global health emergency. The Indonesian government has designated the non-natural disaster of the spread of COVID-19 as a National Disaster. In the face of the non-natural disaster outbreak of COVID-19, a Large-Scale Social Restriction (PSBB) policy was implemented to prevent the transmission of COVID-19. This condition has an impact on the continuity of public health services, including family planning and reproductive health services. This study used quantitative techniques using a quick survey in June-August 2020 using dependent T-test analysis. The sample in this study were 290 respondents. In the results of the bivariate analysis, it was found that there was no difference between the use of contraceptive tools / drugs / methods before and during the http://ejournal.urindo.ac.id/index.php/jukmas

Article History :

Submitted 04 Oktober 2020, Accepted 30 Oktober 2020, Published 310ktober 2020 
pandemic, this is because if we look at the highest percentage of contraceptive tools / drugs / methods used are the IUD, as it is known that the IUD is a Long-acting reversible contraceptives (LARC). The IUD is one of the contraceptives recommended by experts, ensuring proper contraception use during COVID-19 is very important. We encourage women, health workers (midwives, nurses and doctors), policymakers and communities to consider sexual and reproductive health services as priorities.

Keywords: Contraception, IUD, PUS, Pandemic, COVID-19, Family planning

\section{PENDAHULUAN}

Pada Desember 2019, terjangkit pneumonia yang tidak diketahui penyebabnya terdeteksi di Wuhan, China; itu dengan cepat ditentukan sebagai penyebab virus corona baru, yang diidentifikasi sebagai Coronavirus sindrom pernapasan akut parah 2 (SARS-CoV-2)[1] . Wabah tersebut telah menyebar ke 212 negara lainnya dan wilayah, dengan lebih dari empat juta kasus yang dikonfirmasi dan lebih dari 280.000 kematian di seluruh dunia hingga 11 Mei 2020[2]. Oleh karena itu, pada 30 Januari 2020, Organisasi Kesehatan Dunia (WHO) Komite Darurat menyatakan penyakit virus korona (COVID19) sebagai darurat kesehatan global [3]. Menurut Keputusan Presiden No. 12 tahun 2020 tentang Penetapan Bencana non alam penyebaran COVID-19 sebagai Bencana Nasional. Dalam menghadapi wabah bencana non alam COVID-19 ini dilakukan kebijakan Pembatasan Sosial Berskala Besar (PSBB) untuk pencegahan penularan COVID-

19. Kondisi ini menyebabkan dampak terhadap kelangsungan pelayanan kesehatan masyarakat, termasuk pelayanan KB dan kesehatan reproduksi. Pada kondisi pandemi ini diharapkan PUS terutama PUS dengan 4 Terlalu (4T) diharapkan tidak hamil sehingga petugas kesehatan perlu memastikan mereka tetap menggunakan kontrasepsi [4].

Wabah infeksi berpotensi merusak program keluarga berencana; misalnya, distribusi kontrasepsi menurun sebesar $65 \%$ di Liberia dan 23\% di Sierra Leone pada puncaknya Epidemi Ebola Afrika Barat[5]. Pasien dan petugas kesehatan berisiko terinfeksi itu dapat diantisipasi dan ditangani permasalahannya sebelum menjadi masalah besar pada layanan kesehatan selama puncak pandemi COVID19 saat ini akan berlangsung antara 3 dan 6 bulan dengan gangguan tingkat rendah yang berlanjut selama beberapa bulan setelah ini [6]. Karena itu, konseling reproduksi harus dilakukan selama Pandemi COVID-19, berdasarkan pedoman dan makalah terbaru tentang COVID-19 dan kontrasepsi [6]. Perilaku pasangan usia subur dengan adanya aturan PSBB akan ada 
perubahan pastiya seperti mengurangi kunjungan ke fasilitas kesehatan, semua aktifitas berkumpu dirumah baik aktifitas bekerja, sekolah, dan lain lain yang akan berakitabat pada periaku PUS tersebut. Berdasarkan latar belakang tersebut peneliti ingin melihat fenomena perubahan perilaku penggunaan aseptor KB pada masa pendemi COVID-19. Untuk itu, dalam menghadapi pandemi COVID 19 ini, pelayanan tetap dilakukan tetapi dengan menerapkan prinsip pencegahan pengendalian infeksi dan physical distancing. Pandemi COVID-19 merubah pola hidup hampir semua orang, dampak negatif yang merugikan yang memengaruhi pola penggunaan alat kontrasepsi dan mengganggu distribusi obat-obatan dan alat kontrasepsi [7]. Petugas medis yang terlibat dalam layanan kesehatan reproduksi dialihkan untuk memenuhi kebutuhan yang lain dan orang-orang enggan pergi ke fasilitas kesehatan untuk memeriksakan kesehatan reproduksinya termasuk berkunjung untuk menggunakan alat kontrasepsi [8]. Dampak-dampak ini menghadirkan risiko besar bagi kesehatan dan kesejahteraan perempuan dan anak perempuan yang membutuhkan layanan dan produk penggunaan kontrasepsi.[9]

UNFPA telah menekankan bahwa, selama respons pandemi COVID-19, "penyediaan kontrasepsi modern jangka pendek dan jangka panjang, informasi, konseling, dan layanan (termasuk kontrasepsi darurat) dapat menyelamatkan jiwa dan harus tersedia serta dapat diakses. Pendekatan perubahan sosial dan perilaku (Social and behavior change SBC) tetap merupakan alat penting untuk mencapai tujuan ini [10]. Namun, lingkungan baru yang diciptakan akibat pandemi COVID-19 menarik masyarakat untuk menghadapi sejumlah tantangan. Contohnya sebagian besar informasi baru seputar COVID-19, termasuk informasi dan rumor yang melimpah, yang mengarah ke tingkat ketakutan yang tinggi; Kebutuhan untuk mempelajari perilaku baru atau yang dikenal new nomal untuk melindungi diri dari virus; Perubahan pola komunikasi yang khas dan sumber tepercaya, dengan kontak pribadi yang berkurang dan jika dapat diakses harus ada komunikasi virtual yang lebih besar [9] Untuk memastikan kelanjutan akses kontrasepsi dan layanan, termasuk konseling dan keputusan membuat bersama, dibutuhkan sejumlah sistem secara khusus untuk memaksimalkan penggunaan pendekatan "notouch" dan perawatan bila sangat penting [11].

BKKBN menghimbau masyarakat untuk bisa menggunakan Alat Kontrasepsi jangka panjang (MKJP) adalah alat kontrasepsi yang digunakan untuk menunda, menjarangkan kehamilan, serta 
menghentikan kesuburan yang digunakan dengan jangka panjang,yang meliputi IUD (Intra Uterine Device), Implant (susuk KB) dan Kontrasepsi mantap (MOP dan MOW). Metode MKJP dikenal juga dengan istilah LARC (Long-acting reversible contraceptives), Metode LARC/ MKJP merupakan metode yang direkomendasikan pada saat pandemic COVID 19 ini. Pelayanan kontrasepsi untuk pengguna baru jika memungkinkan dengan memadai persiapan keselamatan untuk prosedur ini. Buat aturan untuk menghindari terlalu banyak klien di ruang tunggu, seperti menjadwalkan klien secara individual, agar klien menunggu di luar, dan memastikan klien menejaga jarak sosial yang memadai sementara. Jika MKJP tidak tersedia, tawarkan metode yang alami yang dapat dikendalikan oleh klien[11]. Untuk menjaga agar semua orang aman di rumah, dan terlindungi dari virus, terdapat panduan untuk dokter dan pekerja perawatan kesehatan yang bekerja untuk mempertahankan akses keperawatan kesehatan reproduksi untuk pasien di seluruh negara selama krisis COVID-19 [12]. Perilaku pasangan usia subur dengan adanya aturan PSBB dan adaptasi kebiasaan baru atau new normal akan ada perubahan seperti mengurangi kunjungan ke fasilitas kesehatan, semua aktifitas berkumpu dirumah baik aktifitas bekerja, sekolah, dan lain lain yang akan berakibat pada perilaku pasangan usia subur (PUS). Lebih lanjut, laporan saat ini menunjukkan peningkatan kekerasan dalam rumah tangga terhadap perempuan dan anak-anak selama pandemi COVID19 serta kekerasan berbasis gender, sehingga lebih sulit untuk mencari bantuan atau layanan dan ketersediaan karena penerapan isolasi [9].

\section{METODE}

Penelitian ini menggunakan teknik kuantitatif dengan menggunakan metode survei online pada bulan Juni-Agustus 2020 menggunakan media google form yang disebarkan melalui email, whatsapp grup, facebook, dan media sosial lainnya [13]. Penelitian ini menggunakan analisis deskriptif yang dilakukan untuk menggambarkan karakteristik responden, analisis Uji-T dependen utk membandingkan apakah kedua data variabel tersebut sama atau berbeda, dalam variabel ini yg dilihat perbandingannya adalah cara penggunaan kontrasepsi disusun berdasarkan dari yang paling mempunyai peluang hamil tinggi sampai peluang hamil terendah. Sampel pada penelitian ini sebanyak 290 responden dengan kriteria inklusi perempuan usia subur (19-50 tahun).

\section{HASIL DAN PEMBAHASAN}

Sampel pada penelitian ini sebanyak 290 responden dengan kriteria inklusi 
perempuan usia subur (19-50 tahun). Hasil karakteristik responden menurut umur ditundukkan pada tabel 1 sebagai berikut :

Tabel 1. Distribusi Umur Responden

\begin{tabular}{ccccc}
\hline Variabel & Mean & SD & $\begin{array}{c}\text { Min } \\
- \\
\text { Max }\end{array}$ & $\begin{array}{c}95 \% \\
\mathrm{Cl}\end{array}$ \\
\hline Umur & 33,53 & 6,846 & 19 & 32,74 \\
Responden & & & - & - \\
& & & 55 & 34,32 \\
\hline
\end{tabular}

Berdasarkan tabel 1 didapatkan bahwa rata-rata umur responden adalah 33,53 tahun, dengan variasi 6,85 tahun. Umur termuda responden adalah 19 tahun dan umur tertua adalah 55 tahun. Hasil analisis dapat disimpulkan bahwa rata-rata umur responden berada di antara 32,74 tahun sampai dengan 26,48 tahun.

Tabel 2. Distribusi Karakteristik Responden

\begin{tabular}{lcc}
\hline Variabel & Jumlah & Persentase (\%) \\
\hline Pendidikan & & \\
SD & 14 & 4,8 \\
SMP & 15 & 5,2 \\
SMA & 57 & 19,7 \\
Perguruan & 204 & 70,3 \\
Tinggi & & \\
\hline Wilayah & & \\
Tempat Tinggal & & \\
Perkotaan & 244 & 84,1 \\
Pedesaan & 46 & 15,9 \\
\hline Jumlah Anak & & \\
Kandung & & \\
S2 anak & 220 & 75,9 \\
$>2$ anak & 70 & 24,1
\end{tabular}

\section{Rencana Hamil}

sebelum

Pandemi

\begin{tabular}{lcc} 
Ya & 48 & 16,6 \\
tidak & 242 & 83,4 \\
\hline Rencana Hamil & & \\
saat Pandemi & & \\
Ya & 22 & 7,6 \\
tidak & 268 & 92,4 \\
\hline
\end{tabular}

Berdasarkan Tabel 2 Distribusi Karakteristik Responden terlihat bahwa variabel pendidikan terbanyak didapat oleh responden dengan tingkat pendidikan perguruan tinggi sebanyak 204 (70,3\%) responden, tinggal diperkotaan sebanyak $244(84,1 \%)$ responden, mempunyai anak kandung $\leq 2$ anak sebanyak 220 (75,9\%) responden dengan jumlah anak terkecil adalah 1 dan terbanyak adalah 5 anak. Sebanyak $48 \quad(16,6 \%)$ responden merencanakan kehamilannya sebelum terjadinya pandemi dan berkurang menjadi $22(7,6 \%)$ responden yang merencanakan kehamilan saat terjadi pandemi.

Penelitian ini menggunakan survei cepat dengan media google form yang disebarkan melalui email, dan sosia media seperti whatsapp grup, facebook, dan media sosial lainnya, [13] oleh karena itu memungkinkan diperoleh data penyebaran kuesioner yang tidak merata antara perkotaan $(84,1 \%)$ dan pedesaan $(15,9 \%)$ tidak berimbang, hal tersebut sesuai dengan data yang menyebutkan bahwa dari 171,17 juta jiwa penduduk Indonesia pengguna internet di perkotaan sebanyak $74 \%$ 
sedangkan dipedesaan hanya $62 \%$ memungkinkan untuk akses internet yang terbatas [14].

Dari data terlihat bahwa responden yang mempunyai anak kandung $\leq 2$ anak sebanyak $220(75,9 \%)$ responden dengan jumlah anak terkecil adalah 1 dan terbanyak adalah 5 anak. Sebanyak 48 (16,6\%) responden merencanakan kehamilannya sebelum terjadinya pandemi dan berkurang menjadi $22 \quad(7,6 \%)$ responden yang merencanakan kehamilan saat terjadi pandemi. Terlihat bahwa sebagian responden berniat merencanakan kehamilan sebelum pandemi lebih tinggi dan setelah pandemi mengalami penurunan, hal tersebut wajar mungkin karena ibu khaatir tentang kondisinya ketika hamil, karena ibu hamil merupakan salah satu kelompok rentan. Kondisi kehamilan menyebabkan penurunan kekebalan parsial karena perubahan fisiologi pada saat kehamilan, sehingga mengakibatkan ibu hamil lebih rentan terhadap infeksi virus. Oleh karena itu, pandemi COVID-19 sangat mungkin menyebabkan konsekuensi yang serius bagi ibu hamil [15] [16] [17].

Perubahan fisiologis dan imunologis yang

terjadi pada kehamilan normal dapat memiliki efek sistemik yang meningkatkan risiko komplikasi obstetrik dari infeksi pernapasan pada ibu hamil [18]. Melalui evaluasi yang dilakukan dalam wabah koronavirus sebelumnya (SARS dan MERS), ibu hamil telah terbukti memiliki risiko kematian yang tinggi, keguguran spontan, kelahiran prematur, dan IUGR (intrauterine growth restriction). Tingkat fatalitas SARS dan MERS di antara pasien hamil adalah $25 \%$ dan $40 \%$, masing-masing terdapat beberapa risiko seperti ketuban pecah dini, kelahiran prematur, takikardia janin, dan gawat janin [19]. Namun, Apakah COVID-19 meningkatkan risiko keguguran dan kelahiran mati belum diketahui [15] [20].

Pesan Bagi Masyarakat terkait Pelayanan KB Pandemi COVID-19 sebagai berikut : Menunda kehamilan sampai kondisi pandemi berakhir; Akseptor KB sebaiknya tidak datang ke petugas Kesehatan, kecuali yang mempunyai keluhan, dengan syarat membuat perjanjian terlebih dahulu dengan petugas Kesehatan; Bagi akseptor IUD/Implan yang sudah habis masa pakainya, jika tidak memungkinkan menggunakan kondom; Bagi akseptor Suntik diharapkan datang ke petugas kesehatan sesuai jadwal dengan membuat perjanjian sebelumnya; Bagi akseptor Pil diharapkan dapat menghubungi petugas PLKB atau kader atau Petugas Kesehatan untuk mendapatkan Pil KB dan melakukan cara tradisional; Ibu yang sudah melahirkan sebaiknya langsung menggunakan KB Pasca 
Persalinan (KBPP); Materi Komunikasi, Informasi, dan Edukasi (KIE) serta pelaksanaan konseling terkait KB dapat diperoleh secara online [4].

Tabel 3. Distribusi Alat/Obat/Cara Kontrasepsi Sebelum dan Saat Pandemi

\begin{tabular}{lcccc}
\hline \multicolumn{1}{c}{$\begin{array}{c}\text { Jenis } \\
\text { Alat/Obat/Cara } \\
\text { Kontrasepsi }\end{array}$} & \multicolumn{2}{c}{$\begin{array}{c}\text { Sebelum } \\
\text { Pandemi }\end{array}$} & \multicolumn{2}{c}{ Saat Pandemi } \\
\cline { 2 - 5 } & Jumlah & \% & Jumlah & $\%$ \\
\hline $\begin{array}{l}\text { Senggama } \\
\text { terputus }\end{array}$ & 26 & 9,0 & 25 & $\downarrow 8,6$ \\
$\begin{array}{l}\text { Pantang } \\
\text { berkala/kalender }\end{array}$ & 13 & 4,5 & 17 & $\uparrow 5,9$ \\
Metode & & & & \\
amenore laktasi & 5 & 1,7 & 9 & $\uparrow 3,1$ \\
Kondom & 44 & 15,2 & 49 & $\uparrow 16,5$ \\
$\begin{array}{l}\text { Pil KB } \\
\text { Suntikan 1 bulan }\end{array}$ & 20 & 6,9 & 21 & $\uparrow 7,2$ \\
Suntikan 3 bulan & 45 & 10,3 & 23 & $\downarrow 7,9$ \\
Implant/susuk & 10 & 3,4 & 41 & $\downarrow 14,1$ \\
KB & & & & $\downarrow 3,1$ \\
AKDR/IUD & 78 & 26,9 & 73 & $\downarrow 25,2$ \\
Tubektomi & 7 & 2,4 & 10 & $\uparrow 3,4$ \\
Metode Lainnya & 12 & 4,1 & 13 & $\uparrow 4,5$ \\
Total & 290 & 100 & 290 & 100 \\
\hline
\end{tabular}

Keterangan:

$\downarrow$ mengalami penurunan jumlah saat pandemi

$\uparrow$ mengalami kenaikan jumlah saat pandemi

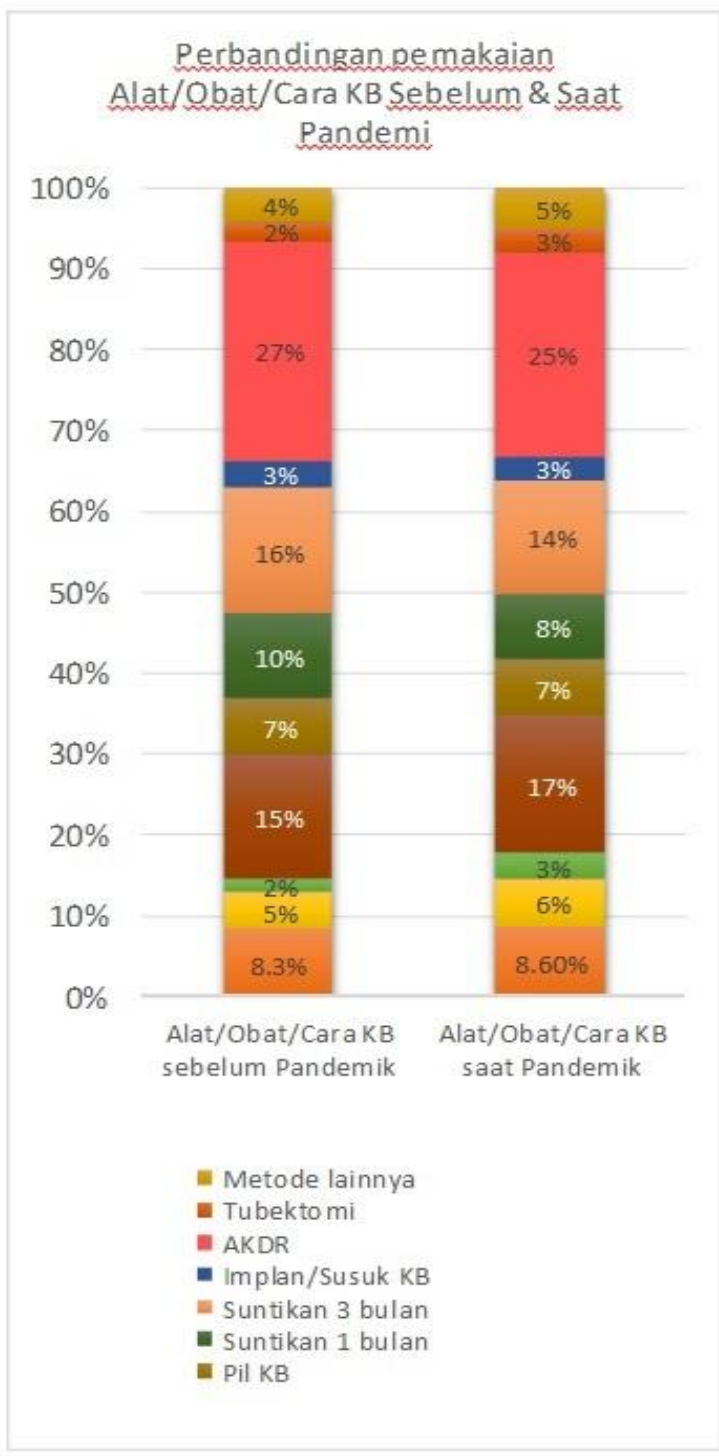

Gambar 1. Perbandingan Pemakaian Alat/Obat/Cara Kontrasepsi Pada Sebelum dan Saat Pandemi

Berdasarkan gambar 1 dan tabel 3 tentang distribusi penggunaan alat/obat/cara kontrasepsi pada masa pandemi terdapat kenaikan maupun penurunan pada penggunaan alat/obat/cara kontrasepsi pada sebelum dan saat pandemi, seperti pada penggunaan AKDR/IUD dari 78 (26,9\%) responden pada sebelum pandemi berkurang menjadi $73(25,2 \%)$ responden 
penggunaannya saat pandemic, hal ini disebabkan karena beberapa responden penggunaan AKDR/IUD yang sudah habis masa pakainya, dikuatkan dengan penggunaan kondom yang semula sebelum pandemi merupakan urutan ketiga terbanyak yaitu sebesar $44 \quad(15,2 \%)$ responden kemudian naik menjadi urutan kedua sebagai alat/obat/cara kontrasepsi yang dipakai saat pandemi 49 (16,9\%) responden.

Tabel 4. Perbedaan Penggunaan Alat/Obat/Cara Kontrasepsi Sebelum dan Saat Pandemik

\begin{tabular}{|c|c|c|c|}
\hline $\begin{array}{c}\text { Alat/Obat/Cara } \\
\text { Kontrasepsi }\end{array}$ & Mean & SD & $p$ value \\
\hline $\begin{array}{l}\text { 1. Sebelum } \\
\text { pandemik }\end{array}$ & 6,28 & 2.806 & 0,165 \\
\hline $\begin{array}{ll}\text { 2. Saat } \\
\text { Pandemik }\end{array}$ & 6,15 & 2.886 & 0,169 \\
\hline
\end{tabular}

Pada hasil analisis bivariat tabel 4 perbedaan penggunaan alat/obat/cara kontrasepsi sebelum dan saat pandemi didapatkan bahwa tidak terdapat perbedaan antara penggunaan alat/obat/cara kontrasepsi sebelum dan saat pandemi, hal ini disebabkan bahwa jika kita lihat persentase tertinggi pada alat/obat/cara kontrasepsi yang digunakan adalah AKDR/IUD, sebagaimana yang diketahui bahwa AKDR/IUD merupakan Metode Kontrasepsi Jangka Panjang (MJKP).

IUD merupakan kontrasepsi yang dimasukkan ke dalam rahim yang terbuat dari

bahan polietilen dengan atau tanpa metal atau steroid [21]. IUD sangat efektif untuk menjarangkan kehamilan dibandingkan dengan

MKJP lainnya seperti tubektomi, vasektomi serta implan. IUD merupakan metode kontrasepsi jangka panjang yang paling banyak digunakan dalam Program KB di Indonesia [22]. Pengguna IUD di Indonesia mencapai $22,6 \%$ dari semua pengguna metode kontrasepsi [23]. Beberapa penelitian menunjukkan bahwa terdapat keuntungan dari penggunaan kontrasepsi ini, antara lain: efektifitasnya tinggi sekitar 0,6 sampai 0,8 kehamilan per 100 perempuan, kegagalan dalam 125 sampai 170 kehamilan; segera efektif saat terpasang di Rahim; tidak memerlukan kunjungan ulang; tidak mempengaruhi hubungan seksual; tidak memiliki efek samping hormonal; tidak mempengaruhi kualitas dan volume ASI; dapat dipasang segera setelah melahirkan atau

sesudah abortus dengan catatan tidak terjadi

infeksi; membantu mencegah kehamilan ektopik; tidak ada interaksi dengan obatobatan; dapat digunakan hingga menopause.

Sedangkan kekurangan dari penggunaan IUD

antara lain: perubahan siklus haid, periode haid lebih lama, perdarahan atau spotting antar menstruasi, nyeri saat haid [21][24].

BKKBN menghimbau masyarakat untuk bisa menggunakan Alat Kontrasepsi jangka panjang (MKJP) adalah alat kontrasepsi yang digunakan untuk menunda, menjarangkan kehamilan, serta menghentikan kesuburan yang digunakan dengan jangka panjang,yang meliputi IUD 
(Intra Uterine Device), Implant (susuk KB) dan Kontrasepsi mantap (MOP dan MOW). Metode MKJP dikenal juga dengan istilah LARC (Long-acting reversible contraceptives), Metode LARC merupakan metode yang direkomendasikan pada saat pandemic COVID 19 ini.

Pelayanan kontrasepsi untuk pengguna baru jika memungkinkan dengan memadai persiapan keselamatan untuk prosedur ini. Buat aturan untuk menghindari terlalu banyak klien di ruang tunggu, seperti menjadwalkan klien secara individual, agar klien menunggu di luar, dan memastikan klien menejaga jarak sosial yang memadai sementara. Jika MKJP tidak tersedia, tawarkan metode yang alami yang dapat dikendalikan oleh klien[11]. Bisa juga memanfaatkan penggunaan teknologi informasi dalam rangka pencegahan COVID19 seperti yang disampaikan melalui Peraturan Menteri Kesehatan Nomor 20 Tahun 2019 tentang Penyelenggaraan Pelayanan Telemedicine Antar Fasilitas Pelayanan Kesehatan dan surat Edaran Nomor HK.02.01/MENKES/303/2020 tentang Penyelenggaraan pelayanan kesehatan melalui pemanfaatan teknologi informasi komunikasi dalam rangka pencegahan penyebaran COVID-19 [14].

Untuk menjaga agar semua orang aman di rumah, dan terlindungi dari virus, terdapat panduan untuk dokter dan pekerja perawatan kesehatan yang bekerja untuk mempertahankan akses keperawatan kesehatan reproduksi untuk pasien di seluruh negara selama krisis COVID-19 [12]. Kontrasepsi selama pandemi COVID-19, dengan penekanan khusus pada keluarga layanan perencanaan, penggunaan jangka panjang metode kontrasepsi jangka panjang (LARC) atau yang dikenal MKJP. Pendapat ahli memastikan penggunaan kontrasepsi yang tepat pada saat COVID-19 sangat penting. Kita mendorong perempuan, tenaga kesehatan (bidan, perawat dan dokter), pembuat kebijakan, dan masyarakat untuk mempertimbangkan layanan seksual dan kesehatan reproduksi sebagai prioritas [25].

\section{KESIMPULAN DAN SARAN}

Dari hasil penelitian didapatkan tidak terdapat perbedaan antara penggunaan alat/obat/cara kontrasepsi sebelum dan saat pandemi, hal ini disebabkan bahwa jika kita lihat persentase tertinggi pada alat/obat/cara kontrasepsi yang digunakan adalah AKDR/IUD, sebagaimana yang diketahui bahwa AKDR/IUD merupakan Metode Kontrasepsi Jangka Panjang (MJKP). IUD merupakan salah satu alat kontrasepsi yang disarankan oleh ahli, memastikan penggunaan kontrasepsi yang tepat pada saat COVID-19 sangat penting. Kita 
mendorong perempuan, tenaga kesehatan (bidan, perawat dan dokter), pembuat kebijakan, dan masyarakat untuk mempertimbangkan layanan seksual dan kesehatan reproduksi sebagai prioritas.

\section{DAFTAR PUSTAKA}

[1] Dong E, Du H G. An interactive webbased dashboard to track COVID-19 in real time. LLancet Infect Dis., 2020, pp. 20(5):533-534.

[2] WHO Health Emergency. WHO (COVID-19) Homepage. WHO Homepage, http://covid19.who.int/ (2020).

[3] Meyer CG Velavan TP. The COVID-19 epidemic. Trop Med Int Heal, 2020, pp. 25:278-280.

[4] Kementrian Kesehatan RI. PELAYANAN KELUARGA BERENCANA DAN KESEHATAN REPRODUKSI DALAM SITUASI PANDEMI COVID 19. 2020.

[5] Bietsch K, Williamson J RM. Family planning during and after the West African Ebola Crisis. Stud Fam Plann 2020; 51:71-86.

[6] P. W. Virtual health care in the era of COVID-19. Lancet, pp. 395:11801181.

[7] Purdy C. Opinion: How will COVID-19 affect global access to contraceptives - and what can we do about it? Devex, 2020.

[8] International Planned Parenthood Federation. COVID-19 pandemic cuts access to sexual and reproductive healthcare for women around the world.

[9] ACTION B. Guidance on Social and Behavior Change for Family Planning During COVID-19. Impact, Planning, Fam 2020; 1-5.

[10] United Nations Population Fund UNFPA. Coronavirus Disease (COVID19) Preparedness and Response UNFPA Interim Technical Brief. 2020.

[11] World Health Organization WHO. Critical preparedness, readiness and response actions for COVID-19.

[12] Duration L, Ocps I, Chc F, et al. Contraception in the time of COVID19. 2020; 216: 2-3.

[13] Shih TH and X. Comparing response rates from web and mail surveys: $A$ meta-analysis'. Field methods; 20(3): 249-271.

[14] dr. Bambang Wibowo, Sp.OG (K) M. PEMANFAATAN TEKNOLOGI INFORMASI DALAM RANGKA PENCEGAHAN PENYEBARAN COVID 19. 2020.

[15] Anung Ahadi Pradana, Casman N. PENGARUH KEBIJAKAN SOCIAL DISTANCING PADA WABAH COVID- 
19 TERHADAP KELOMPOK RENTAN

DI INDONESIA. J Kebijak Kesehat Indones JKKI 2020; 09: 61-67.

[16] Breslin N, Baptiste C G, C, Miller R, Bernstein K, Ring L et al. COVID-19 infection among asymptomatic and symptomatic pregnant women: Two weeks of confirmed presentations to an affiliated pair of New York City hospitals. Am J Obs Gynecol MFM; 100118.

[17] Liang H AG. Novel corona virus disease (COVID-19) in pregnancy: What clinical recommendations to follow? Acta Obs Gynecol Scand 2020; 99: 439-42.

[18] DA S. An Analysis of 38 Pregnant Women with COVID-19, Their Newborn Infants, and Maternal-Fetal Transmission of SARS-CoV-2: Maternal Coronavirus Infections and Pregnancy Outcomes. Arch Pathol Lab Med.

[19] Karami P, Naghavi M FA, Aghamohammadi $M$, Sadegh M MA, Al E. Mortality of a pregnant patient diagnosed with COVID-19: A case report with clinical, radiological, and histopathological fi ndings. Travel Med Infect Dis; April.

[20] Rasmussen SA, Smulian JC LJ, Wen TS JD. Coronavirus Disease 2019 (COVID-19) and Pregnancy: What obstetricians need to know. Am J Obs Gynecol; 1-12.

[21] Putri RP, Oktaria D, Kedokteran F, et al. Efektivitas Intra Uterine Devices ( IUD ) Sebagai Alat Kontrasepsi Effectivity of Intra Uterine Devices ( IUD ) as a Contraception Devices.

[22] Wa A, Machmudah NU. Gambaran pola menstruasi pada akseptori Intra Uterine Device (IUD) di wilayah kerja Puskesmas Kedungmundu Semarang. J Keperawatan Matern 2013; 1(1): 28-36.

[23] Berencana BKK, (BKKBN) N. Perkembangan Pencapaian Peserta KB Baru menurut Alat Kontrasepsi. $B K K B N$, http//www.bkkbn.go.id/.

[24] Nilakusumawati DPE GN. Studi Operasional Peningkatan Pemakaian Kontrasepsi IUD di Provinsi Bali. Kependud dan Pengemb Sumber Daya Manusia 2012; 02: 103-113.

[25] Edson Santos Ferreira-Filho a, Nilson Roberto de Melo a ICES a, Luis Bahamondes b, Ricardo Dos Santos Simões a JMS-J a and ECB. Contraception and reproductive planning during the COVID-19 pandemic. Expert Rev Clin Pharmacol 2020; 13: 615-622. 